\title{
Generation and evaluation of a monoclonal antibody, designated MAdL, as a new specific marker for adenocarcinomas of the lung
}

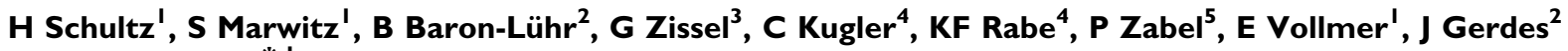 \\ and T Goldmann*,I \\ 'Clinical and Experimental Pathology, Research Center Borstel, Parkallee I-40, D-23845 Borstel, Germany; ${ }^{2}$ Tumor Biology, Research Center Borstel, \\ Parkallee I-40, D-23845 Borstel, Germany; ${ }^{3}$ Department for Pneumology, University of Freiburg, Killianstrasse 5, D-79 106 Freiburg, Germany; ${ }^{4}$ Hospital \\ Großhansdorf, Wöhrendamm 80, D-22927 Großhansdorf, Germany and ${ }^{5}$ Medical Clinic, Research Center Borstel, Parkallee I-40, D-23845 Borstel, \\ Germany
}

\begin{abstract}
BACKGROUND: Different therapy regimens in non-small-cell lung cancer (NSCLC) are of rising clinical importance, and therefore a clear-cut subdifferentiation is mandatory. The common immunohistochemical markers available today are well applicable for subdifferentiation, but a fraction of indistinct cases still remains, demanding upgrades of the panel by new markers.

METHODS: We report here the generation and evaluation of a new monoclonal antibody carrying the MAdL designation, which was raised against primary isolated human alveolar epithelial cells type 2 .

RESULTS: Upon screening, one clone (MAdL) was identified as a marker for alveolar epithelial cell type II, alveolar macrophages and adenocarcinomas of the lung. In a large-scale study, this antibody, with an optimised staining procedure for formalin-fixed tissues, was then evaluated together with the established markers thyroid transcription factor-I, surfactant protein-A, pro-surfactant protein-B and napsin A in a series of 362 lung cancer specimens. The MAdL displays a high specificity (>99\%) for adenocarcinomas of the lung, together with a sensitivity of $76.5 \%$, and is capable of delivering independent additional diagnostic information to the established markers.

CONCLUSION: We conclude that MAdL is a new specific marker for adenocarcinomas of the lung, which helps to clarify subdifferentiation in a considerable portion of NSCLCs.

British Journal of Cancer (201 I) 105, 673-68I. doi:I0.1038/bjc.201 I.28I www.bjcancer.com

Published online 2 August 201।

(c) 201। Cancer Research UK
\end{abstract}

Keywords: lung cancer; adenocarcinoma; marker; immunohistochemistry; TTF-I; SP-B

Lung cancer is one of the leading causes of death worldwide, with a still rising incidence (Van Lerberghe et al, 2008). There are longstanding differences between the treatment regimens for the main subtypes of lung cancer, which is primarily divided into small-cell lung cancer (SCLC) and non-SCLC (NSCLC). Differentiation among SCLC, NSCLC and also metastases is of large therapeutic relevance. With regard to this, appropriate immunohistochemical procedures have been developed (Kaufmann et al, 1997).

Novel chemotherapeutic approaches have recently been developed for NSCLC, which is largely known as a chemoresistant tumour. In the respective clinical studies, substantial differences between adenocarcinomas and squamous cell carcinomas or different types of large-cell carcinomas have been shown with regard to the adequate therapeutic regimens (Smit et al, 2001; Esteban et al, 2009; Kim et al, 2009; Lee et al, 2009). Therefore, subdifferentiation of NSCLC, which to some degree has been an academic issue in the past, is currently getting more into focus as increasingly becoming a check element within therapeutic decisions.

*Correspondence: Dr T Goldmann; E-mail: tgoldmann@fz-borstel.de Received 6 April 201।; revised 27 June 201।; accepted I July 201 I; published online 2 August 201I
For such subdifferentiation strategies among NSCLC, different elements of the pulmonary surfactant system repeatedly proved to be reliable markers for adenocarcinomas of the lung. These comprise members of the surfactant proteins themselves, such as surfactant protein-A (SP-A) and pro-surfactant protein-B (SP-B), which are highly specific markers but lack sensitivity (Mizutani et al, 1988; Brasch et al, 2003). Thyroid transcription factor-1 (TTF-1), a positive regulator of surfactant protein promoter activity, has emerged as a major and sensitive marker for a lung cancer, but is not up to differentiate the different entities of pulmonary cancer, such as adenocarcinoma, large-cell neuroendocrine carcinoma, small-cell carcinoma or carcinoid (Folpe et al, 1999; Barlési et al, 2005). In addition, it designates thyroid carcinomas and their metastases (Boggaram et al, 2003; Kargi et al, 2007). The aspartic protease family member napsin A is involved in processing of SP-B in alveolar epithelial cell type II (AECII), and can be used as a marker for adenocarcinomas of the lung (Chuman et al, 1999; Hirano et al, 2003; Dejmek et al, 2007).

Despite the information obtained by the use of these established markers, there is still a need for additional diagnostic information in a portion of NSCLC.

With regard to this, we initialised a screening approach starting with immunisation of mice against human primary AECII (Zissel 
et al, 2000). After generation of numerous hybridomas, the corresponding monoclonal antibodies were subjected to primary screening using cell cultures and human tissues. One of the clones directed against a cytoplasmic fraction of AECII showed reactivity with AECII, alveolar macrophages and adenocarcinomas of the lungs, which was further verified using tissue microarrays (TMAs) from NSCLC tissues treated with the HOPE technique (Srinivasan et al, 2002; Goldmann et al, 2003, 2005). This clone was designated MAdL (marker for adenocarcinomas of the lung). Subsequently, an optimised protocol for the use of MAdL on formalin-fixed, paraffin-embedded (FFPE) tissues was developed. Here, we present the results of the use of MAdL in addition to the above-mentioned established markers.

\section{MATERIALS AND METHODS}

\section{Primary human AECII}

Samples from macroscopically tumour-free lung tissue were cut from the surgical specimens and used for cell isolation procedure as described previously (Pechkovsky et al, 2005, 2006). In brief, the lung tissue was first sliced and slices were washed three times at $4{ }^{\circ} \mathrm{C}$ in PBS. The washed slices were incubated in sterile dispase solution at $37^{\circ} \mathrm{C}$ for $45 \mathrm{~min}$. After dispase digestion, the lung tissue slices were cut into small, pipetable pieces and thoroughly pipetted for several minutes. Crude tissue and cell suspensions were filtered through nylon gauze with meshes of $100 \mu \mathrm{m}, 50 \mu \mathrm{m}$ and $20 \mu \mathrm{m}$. The resulting single-cell suspension was placed on Ficoll separating solution and centrifuged at $800 \mathrm{~g}$ for $20 \mathrm{~min}$. The AECII-enriched cells from the interphase were washed and incubated in $100 \mathrm{~mm}$ plastic dishes at $37{ }^{\circ} \mathrm{C}$ in humidified air containing $5 \% \mathrm{CO}_{2}$ for 15 , 20 and $30 \mathrm{~min}$, with seeding of non-adherent cells on fresh dishes for each time interval to remove adherent cells (alveolar macrophages, monocytes, fibroblasts and endothelial cells). To remove remaining monocytes/macrophages and lymphocytes, antibodies against CD3 (OKT3 and ECACC 86022706) and CD14 (HB-246 ATCC) were added and the antibody-binding cells were removed by anti-mouse IgG-coated magnetic beads and magnetic activated cell sorting (MACS) system (Miltenyi Biotec, Bergisch Gladbach, Germany), as suggested by the supplier. Identity of type II alveolar epithelial cells was confirmed by a modified Papanicolaou staining, their alkaline phosphatase activity and SP-A mRNA expression in RT-PCR (see below). Cell purity was assessed by immunoperoxidase staining with monoclonal antibodies directed against CD3 and CD14 (Immunotech, Marseille, France) as previously described (20). Viability of the AECII after isolation was $>97 \%$, as determined by trypan blue exclusion. After the final step of MACS purification, the AECII preparations included in this report were free of $\mathrm{CD} 14+$ and $\mathrm{CD} 3+$ cells, as determined by immunocytochemistry. In all, $98 \pm 1.3 \%$ of cells were identified as AECII by the presence of dark blue inclusions, as revealed by modified Papanicolaou staining, and $93 \pm 2.1 \%$ of cells were positive for alkaline phosphatase (data not shown).

\section{Generation of the monoclonal antibody}

A total of $1 \times 10^{7}$ cells were thawed and washed twice in $0.9 \%$. NaCl solution. Subsequently, the cells were lysed in $1 \mathrm{ml}$ lysis solution $(0.9 \% \mathrm{NaCl}$ and $0.5 \%$ Tween 20$)$ and vortexed for $1 \mathrm{~min}$. The lysate was cleared by centrifugation at $34 \mathrm{~g}$ for $15 \mathrm{~min}$ and the supernatant stored at $-20^{\circ} \mathrm{C}$. A female Balb $\mathrm{C}$ mouse was immunised by subcutaneous injections using a mixture of cell lysate and GERBU Adjuvant MM (Gerbu Biotechnik, Gaiberg, Germany): day $0,60 / 40 \mu \mathrm{l}$; days 14 and $21,30 / 20 \mu \mathrm{l}$; and days 28,29 and $30,50 \mu \mathrm{l}$ lysate only. To generate antibody-producing hybridoma lines, spleen cells of this mouse were fused on day 31 with $\times 63$ Ag8.6.5.3 myeloma cells using a standard PEG-based procedure (Köhler and Milstein, 1975). Antibody clones were assessed for their staining pattern using cytospins of primary AECII cells as well as sections of normal human lung and tonsil.

\section{Immunohistochemistry}

For a preliminary study of the immune reactivity of MAdL, TMAs were produced from 35 HOPE-fixed, paraffin-embedded NSCLC tissues as previously described (Goldmann et al, 2005). HOPEfixed specimens allow immunohistochemistry (IHC) without antigen retrieval (AR), which could create artefacts in staining or morphology (Goldmann et al, 2003).

For immunodetection of MAdL, $1 \mu \mathrm{m}$ thick sections of HOPEfixed, paraffin-embedded tissues were deparaffinised by two times of incubation in isopropanol for $10 \mathrm{~min}$ at $65^{\circ} \mathrm{C}$. Deparaffinised sample slides were air dried at room temperature and rehydrated for $10 \mathrm{~min}$ in $70 \%(\mathrm{v} / \mathrm{v})$ acetone/DEPC-treated water at $4{ }^{\circ} \mathrm{C}$. Remaining acetone was removed by incubation for $10 \mathrm{~min}$ in DEPC-treated water at $4{ }^{\circ} \mathrm{C}$ and transferred into distilled water at room temperature. Endogenous peroxidases were blocked for $10 \mathrm{~min}$ in $3 \% \mathrm{H}_{2} \mathrm{O}_{2}$ solution. A volume of $2 \mu \mathrm{g} \mathrm{ml}^{-1}$ of isolated MAdL was diluted with antibody diluent (Zytomed Systems, Berlin, Germany) and applied for $60 \mathrm{~min}$ in a moist chamber. For blocking and detection, a HRP-conjugated polymer kit according to the manufacturer's instructions (Zytomed Systems) was used. Washing steps were carried out three times for $5 \mathrm{~min}$ after each reagent step with washing buffer $(50 \mathrm{~mm}$ Tris saline buffer with $0.1 \%(\mathrm{v} / \mathrm{v})$ Tween $20 ; \mathrm{pH}$ 7.6). Negative controls were included under omission of secondary antibody. Permanent AEC (permanent AEC Kit, Zytomed Systems) was used as substrate for HRPconjugated polymer. Colour reaction was stopped with distilled water. Samples were dehydrated in increasing concentrations of ethanol, washed for $20 \mathrm{~s}$ in xylene and cover slips were mounted using Pertex (Medite, Burgdorf, Germany) as mounting medium.

\section{IHC with MAdL on FFPE tissues}

As most tissue specimens are classically fixed with $4 \%$ neutralbuffered formalin in routine diagnostics, IHC has usually faced the cross-linking effects (Srinivasan et al, 2002) before conducting immunodetection. To increase the diagnostic value, MAdL had therefore to be applicable on FFPE specimens. For an optimal staining result on FFPE specimens, heat-induced AR was tested with acidic, as well as alkaline buffers and standard enzymatic digests (see Table 1). Finally, enzyme-based pretreatment with Fast Enzyme (Zytomed Systems) for $3 \mathrm{~min}$ at ambient temperature or Proteinase XXV (Thermo Fisher Scientific, Waltham, MA, USA) for $10 \mathrm{~min}$ at ambient temperature turned out to provide the best results.

Immunohistochemistry with FFPE tissues was generally conducted as mentioned above, with the exception that FFPE-tissue slides were deparaffinised by incubation in xylene $(2 \times 10 \mathrm{~min})$ and subsequent rehydration in a graded ethanol series for $2 \mathrm{~min}$ each step $(2 \times 100,2 \times 96,90,80,70 \%, 2 \times$ distilled water $)$. The primary antibodies were applied for $1 \mathrm{~h}$ at ambient temperature as described in Table 2. Negative controls were included under omission of primary antibody in each staining series, as well as positive reference sections from human lung to ensure even results.

\section{Screening for cross-reactivity in malignant and non-malignant human tissues}

For evaluation of affinity and cross-reactivity in human tissues, the antibody was tested on various malignant pulmonary (see Table 3) and non-malignant tissues (see Table 4) from either the lung or the other functional systems. In short, the expression of MAdL, in addition to its expression in human lung adenocarcinomas, was 
Table I Assessment of AR for MAdL on FFPE specimens

\begin{tabular}{llll}
\hline Result (+) $\mathbf{( - )}$ & Tested AR & Applied conditions & Producer \\
\hline+++ & Fast enzyme & $3 \mathrm{~min}$ ambient temperature & Zytomed Systems, Berlin, Germany \\
++ & Proteinase XXV & $10 \mathrm{~min}$ ambient temperature & Thermo Fisher Scientific, Waltham, MA, USA \\
+ & Ficin & $5-10 \mathrm{~min}, 37^{\circ} \mathrm{C}$ & Zytomed Systems, Berlin, Germany \\
- & Saponin $(0.05 \%)$ & $30 \mathrm{~min}$ ambient temperature & Serva Electrophoresis, Heidelberg, Germany \\
- & Proteinase K & $10 \mathrm{~min}, 37^{\circ} \mathrm{C}$ & Qiagen, Hilden, Germany \\
- & Pepsin & $10 \mathrm{~min}, 37^{\circ} \mathrm{C}$ & Merck, Darmstadt, Germany \\
- & Citric acid buffer, pH 6 & $30 \mathrm{~min}, 90^{\circ} \mathrm{C}$ & Self-mixed (IO mM citric acid, 0.05\% Tween 20) \\
- & Tris-EDTA, pH 9 & $30 \mathrm{~min}, 90^{\circ} \mathrm{C}$ & Zytomed Systems, Berlin, Germany \\
\hline
\end{tabular}

Abbreviations: $A R=$ antigen retrieval; FFPE $=$ formalin fixed, paraffin embedded. Result: $-=$ unsufficient staining quality; $+=$ week staining quality; $++=$ moderate staining quality; $+++=$ good staining quality.

Table 2 Applied antibodies and AR for immunohistochemistry

\begin{tabular}{|c|c|c|c|}
\hline Antigen & Clone and producer & Dilution $\left(\mu \mathrm{g} \mathrm{ml}^{-1}\right)$ & Applied antigen retrieval \\
\hline MAdL & MAdL, Research Center Borstel, Germany & 2 & Fast enzyme, 3 min at ambient temperature \\
\hline TTF-I & SPT24, DCS, Hamburg, Germany & 1/300 & Citric acid buffer, $\mathrm{pH} 6,30 \mathrm{~min}, 90^{\circ} \mathrm{C}$ \\
\hline SP-B & SPM- I58, Zytomed Systems, Berlin, Germany & $1 / 50$ & Citric acid buffer, $\mathrm{pH} 6,30 \mathrm{~min}, 90^{\circ} \mathrm{C}$ \\
\hline Napsin & KCGI.I, Zytomed Systems, Berlin, Germany & 1/200 & Citric acid buffer, $\mathrm{pH} 6,30 \mathrm{~min}, 90^{\circ} \mathrm{C}$ \\
\hline CK 5/6 & D5/I6B4, DakoCytomation, Glostrup, Denmark & $1 / 100$ & Tris-EDTA, pH $9,30 \mathrm{~min}, 90^{\circ} \mathrm{C}$ \\
\hline
\end{tabular}

Abbreviations: $\mathrm{AR}=$ antigen retrieval; $\mathrm{CK}=$ cytokeratin; $\mathrm{SP}=$ surfactant protein; $\mathrm{TTF}=$ thyroid transcription factor.

Table 3 Investigated specimens

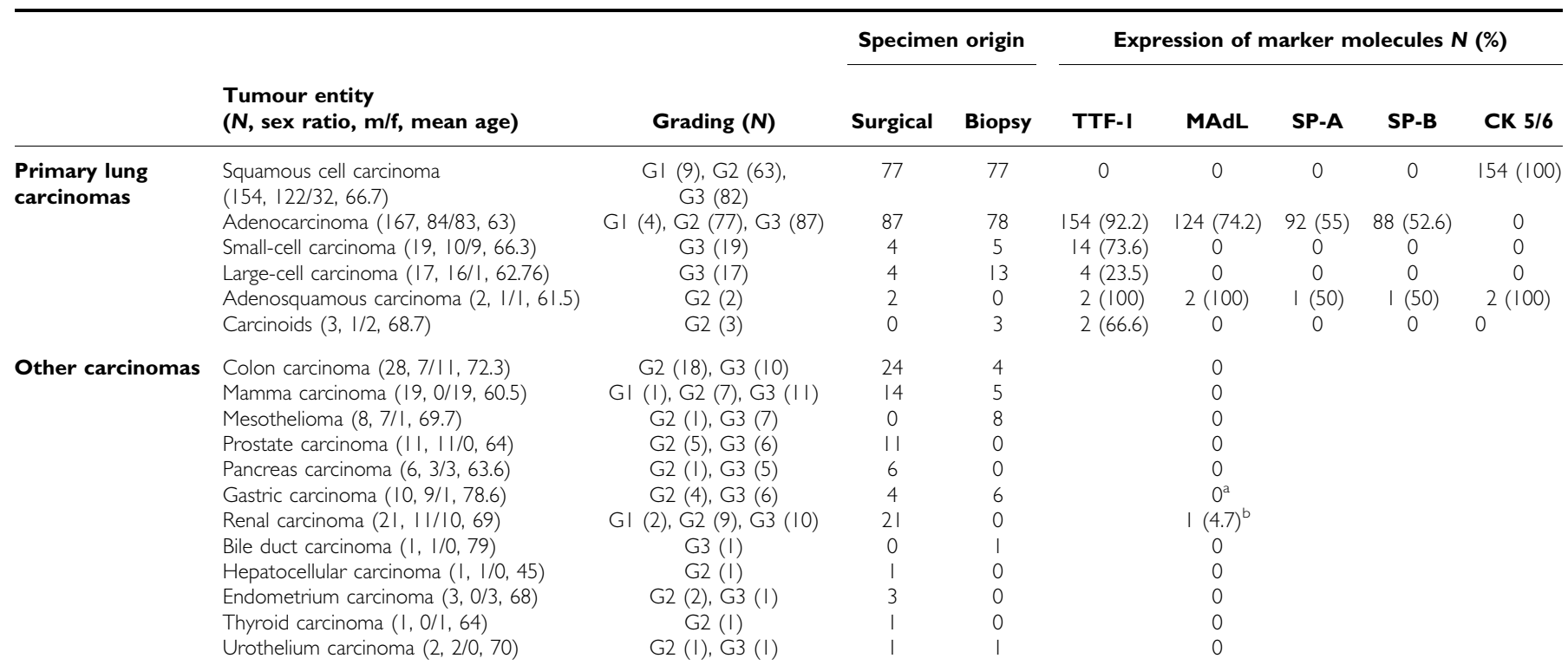

Abbreviations: $\mathrm{CK}=$ cytokeratin; $\mathrm{f}=$ female; $\mathrm{m}=$ male; $\mathrm{SP}=$ surfactant protein; $\mathrm{TTF}=$ thyroid transcription factor. ${ }^{\mathrm{a}}$ Not relevant for diagnostics. ${ }^{\mathrm{b}} \mathrm{Chromophile}$ renal cell carcinoma.

investigated in the most common lung-metastasising tumours. To exclude false-positive reactions with other non-malignant tissues, MAdL was analysed for expression in any functional system, including digestive and urogenital tract, as well as connective tissue, nervous system, endocrine organs and the skin.

\section{Study group}

Patient materials were obtained from either lobectomy, pneumonectomy or peribronchial biopsy at the Hospital of Großhansdorf or Medical Clinic Borstel, Germany. All used archived FFPE tissue blocks were of pathologically and clinically proven diagnosis.
The expression of MAdL was evaluated and compared with common markers for adenocarcinomas of the lung in 362 primary lung carcinomas. The group consisted of 154 squamous cell carcinomas, 167 adenocarcinomas, 2 adenosquamous carcinomas, 19 small-cell carcinomas, 17 large-cell carcinomas and 3 carcinoids. From each diagnosis, an almost comparable amount of specimens was used from either surgical or biopsy origin, in order to compare possible expression differences (260 surgical specimens and 201 biopsy specimens). In addition to primary lung carcinomas, expression of MAdL was investigated in 111 nonpulmonary carcinomas. This series comprised of 28 colon carcinomas, 19 mamma carcinomas, 11 prostate carcinomas, 6 pancreas carcinomas, 10 gastric carcinomas, 21 kidney 
Table 4 Expression of MAdL in non-malignant tissues

\begin{tabular}{|c|c|c|}
\hline Investigated tissues & No expression & Expression \\
\hline Respiratory system & $\begin{array}{l}\text { Respiratory epithelia } \\
\text { Peribronchial glands } \\
\text { Pneumocyte type I }\end{array}$ & $\begin{array}{l}\text { Pneumocyte type II } \\
\text { Alveolar macrophages }\end{array}$ \\
\hline Digestive tract & $\begin{array}{l}\text { Gastric mucosa } \\
\text { Duodenum mucosa } \\
\text { Small-intestine mucosa } \\
\text { Colon mucosa } \\
\text { Liver parenchyma } \\
\text { Bile duct and bladder } \\
\text { Pancreas parenchyma }\end{array}$ & \\
\hline \multicolumn{3}{|l|}{ Urogenital tract } \\
\hline $\begin{array}{l}\text { Kidney } \\
\text { Efferent urinary system } \\
\text { Prostate } \\
\text { Testis }\end{array}$ & $\begin{array}{l}\text { Tubules, glomeruli } \\
\text { Urothelia } \\
\text { Seminal vesicle } \\
\text { Seminal epithelia }\end{array}$ & Proximal tubules \\
\hline Connective tissue & $\begin{array}{l}\text { Smooth/skeletal muscles } \\
\text { Heart muscle } \\
\text { Adipocytes } \\
\text { Fibroblasts }\end{array}$ & \\
\hline Nervous system & $\begin{array}{l}\text { Nerve (autonomous } \\
\text { and somatic) } \\
\text { Ganglions } \\
\text { Brain }\end{array}$ & \\
\hline Endocrine organs & $\begin{array}{l}\text { Adrenal gland } \\
\text { Pituitary gland } \\
\text { Thyroid gland } \\
\text { Parathyroid gland } \\
\text { Langerhans islet cells }\end{array}$ & \\
\hline Skin & $\begin{array}{l}\text { Epidermis } \\
\text { Melanocytes } \\
\text { Integumentary appendage }\end{array}$ & \\
\hline
\end{tabular}

carcinomas, 1 bile duct carcinoma, 1 hepatocellular carcinoma, 1 thyroid carcinoma, 3 endometrium carcinomas and 2 urothelium carcinomas, as well as 8 cases of epitheloid mesothelioma. Detailed diagnostic information for each diagnosis is summarised in Table 3.

Diagnosis and grading of investigated specimens was conducted according to the WHO Classification of Tumours 2004.

\section{RESULTS}

\section{Establishing of IHC and screening of non-malignant tissues}

In a prescreening study, HOPE-fixed carcinomas of the lung were investigated by application of MAdL culture supernatants without any AR. In all, $80 \%$ of investigated adenocarcinomas (16 out of 20 ) were positive and displayed a cytoplasmic, granular signal in epithelia of the tumour. All tested squamous cell carcinomas (20) were negative for MAdL (data not shown).

Results of the prescreening study were verified on formalinfixed adenocarcinomas under equal conditions after establishing optimal AR conditions. A broad range of commonly used AR methods has been applied and compared to optimise the MAdL staining protocol with FFPE tissues. No heat-induced AR, with both acidic and alkaline buffer, resulted in reasonable staining. The same holds true for enzymatic digests with proteinase $\mathrm{K}$, trypsin and pepsin. The best results were obtained by applying fast enzyme and proteinase XXV. Saponin was used as a permeabilisation agent (Pignal et al, 1982) and Ficin provided positive staining, but the staining was less intense when compared with fast enzyme or proteinase XXV treatment (Table 1).

After the setup of a standard staining protocol for FFPE tissues, immunolocalisation of MAdL displayed positive cytoplasmic signals in AECII as well as in intra-alveolar macrophages (Figure 1A). No signal was seen in bronchi and referring glands, respiratory epithelia, type 1 pneumocytes, mesenchymal cells and inflammatory infiltrates. To exclude any false-positive signals, a variety of non-malignant and non-respiratory tissues were further investigated for expression of MAdL. Within the analysed tissues, only the proximal tubules of the kidney displayed immunoreactivity with MAdL (Figure 1C and Table 4), this is in line with its expression in chromophile renal cell carcinoma (Figure 1D). No staining was found in lymphoid tissue (Figure $1 \mathrm{E}$ and $\mathrm{F}$ )

\section{Comparison of MAdL expression with common markers for adenocarcinomas of the lung}

For investigation of MAdL expression and comparison with common applied markers for diagnosis of adenocarcinomas of the lung, a cohort of lung carcinomas was screened. All specimens were analysed for expression of MAdL, TTF-1, SP-A, SP-B and, in case of squamous cell carcinoma, cytokeratin 5/6.

Results for all the markers are displayed in Table 3, including histomorphological entities and expression profiles. In case of adenocarcinomas, $90.2 \%$ showed positive expression of TTF- 1 and $74.2 \%$ were positive for MAdL. Staining targeting the surfactant proteins SP-A and SP-B revealed $55 \%$ and $52.6 \%$ positivity, respectively (Figure 2A). No expression of TTF-1, MAdL, SP-A and SP-B could be observed in squamous cell carcinomas, whereas all of them displayed a positive signal for cytokeratin 5/6. Neither small-cell and large-cell carcinomas, nor carcinoids were positive for MAdL or surfactant proteins. On the contrary, TTF-1 expression was observed in $73.6 \%$ of small-cell carcinomas, in $23.5 \%$ of large-cell carcinomas and in $66.6 \%$ of atypical carcinoids. The two investigated adenosquamous lung tumours were all positive for TTF-1 and MAdL in adenoid-differentiated part and CK 5/6 in squamous-differentiated part, respectively. Only one case was positive for both SP-A and SP-B. Within the group of non-pulmonary tumours, MAdL immunoreactivity could only be observed in one case of chromophile renal cell carcinoma (Figure 1D). Other investigated subtypes of renal carcinoma such as papillary and clear-cell renal cell carcinoma showed no expression.

\section{Marker expression depending on tumour grading and specimen origin}

Regarding the grading of investigated adenocarcinomas, only a small number (four) were low-grade (G1) carcinomas. The majority (77 cases) consisted of intermediate- (G2) and 87 cases of high-grade carcinomas (G3). In routine diagnostics, the intermediate- and high-grade adenocarcinomas of the lung are far more frequent. Therefore, it is helpful to have a marker at hand, which maintains its expression qualitatively even in poorly differentiated carcinomas. With respect to TTF-1, its expression did not reduce dramatically in intermediate- and high-grade adenocarcinomas. The novel aspartic proteinase napsin A showed a comparable sensitivity in intermediate carcinomas to TTF-1. In high-grade carcinomas, its expression declined to a sensitivity of $70.6 \%$. The MAdL revealed the same sensitivity as the other markers in low-grade adenocarcinomas. There is no notable decline in sensitivity from intermediate- to high-grade cases, albeit the overall sensitivity is less than TTF-1 and napsin A. Surfactant protein-A and -B share a comparable sensitivity with MAdL in intermediate-grade cases, whereas their expression ceased notably in high-grade carcinomas (Figure 2B). 

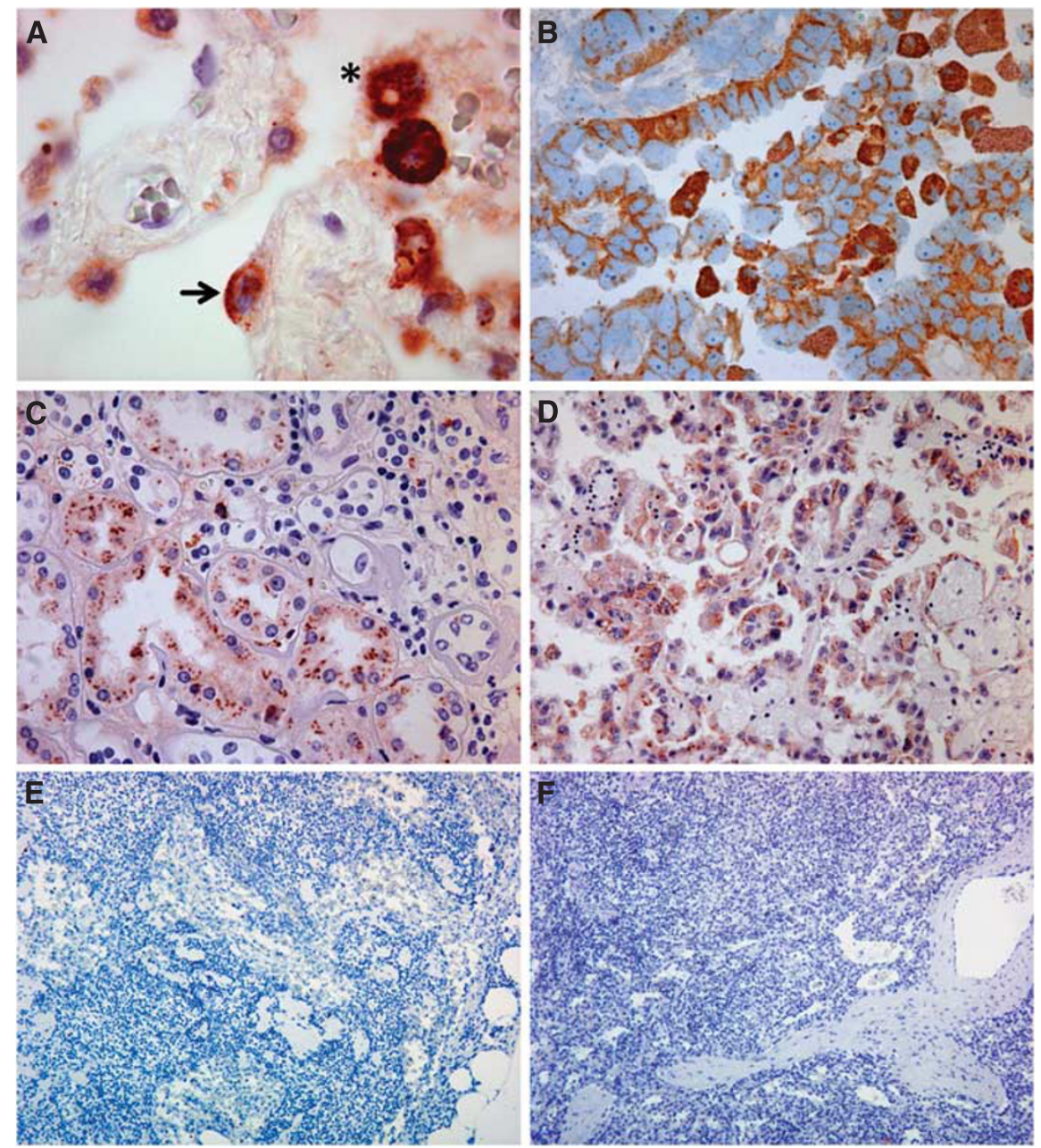

Figure I Photomicrograph of IHC on FFPE tissues targeting MAdL, with red colour indicating positive signal. Immunoreactivity of MAdL in AECII (indicated with arrow) and intra-alveolar macrophages (indicated with star; $\mathbf{A}, \times 1000$, indicated with arrows), as well as a case of corresponding adenocarcinoma of the lung $(\mathbf{B}, \times 400)$ is depicted in the upper part. Non-malignant tissues of proximal kidney tubules $(\mathbf{C}, \times 200)$ as well as chromophile renal cell carcinoma $(\mathbf{D}, \times 200)$ are shown in the centre lane. Lymph node $(\mathbf{E}, \times 200)$ and spleen tissue $(\mathbf{F}, \times 200)$ housing non-alveolar macrophages are all negative for MAdL.

As a growing number of samples results from diagnostic biopsies, we intended to analyse and compare the sensitivity of MAdL and other markers between specimens of surgical and biopsy origin. Regarding TTF-1, there was a high sensitivity $(>75 \%)$ in both surgical and biopsy specimens. Interestingly, it could be observed that in surgical specimens, the sensitivity of MAdL was even a little bit higher compared with TTF-1. The surfactant proteins SP-A and SP-B showed a moderate expression in surgical tissues (57\% and 56\%, respectively). Emphasising on biopsy tissues, MAdL displayed moderate sensitivity (56\%) in contrast to SP-A and SP-B, which declined to 44.9 and $41 \%$, respectively (Figure $2 \mathrm{C}$ ).

\section{Expression patterns of TTF-1, MAdL, SP-A and SP-B in adenocarcinomas of the lung}

Among the investigated 167 cases of adenocarcinomas, the majority was positive for all the applied markers (32.7\%). Thyroid transcription factor-1 expression alone was observed in $21(12.5 \%)$ and MAdL alone in $2(1.2 \%)$ cases. Within the investigated group, the expression of both TTF-1 and MAdL comprised about 25 cases $(14.9 \%)$ and was the second most prevalent observed pattern. A combination of either TTF-1, MAdL and SP-B (9.5\%), or TTF-1, MAdL and SP-A (12.5\%) was of third most incidence (Figure 3).

\section{MAdL in comparison with TTF-1, SP-A and SP-B}

In addition to routine cases in diagnostics, there are repeating situations with aberrant histological specimen. As depicted in Figure 4, a pleura carcinosis from a pulmonary adenocarcinoma was negative for both SP-A and SP-B. Addressing TTF-1 could only confirm pulmonary origin of the carcinoma, although analysis of MAdL expression revealed the specific subtype. The same holds true for mixed tumour entities, which might have a squamous- as well as an adenoid-differentiated component (Figure 5). Cytokeratins 5 and 6 detect the squamous component in the left part of the photomicrograph, and TTF-1 is found to be expressed in a subgroup of glands. In contrast to SP-B, which only provides a patchy and weak signal, MAdL is expressed in the majority of adenoid glands.

\section{DISCUSSION}

\section{Establishing MAdL staining protocol}

The requirements of antibodies as markers in daily routine diagnostics have to face the molecular characteristics of the specimen analysed. As most tissues are traditionally FFPE, an AR is indispensable because of formalin's cross-linking drawbacks (Srinivasan et al, 2002). New markers have to meet these circumstances in order to become widely applicable. As it is 

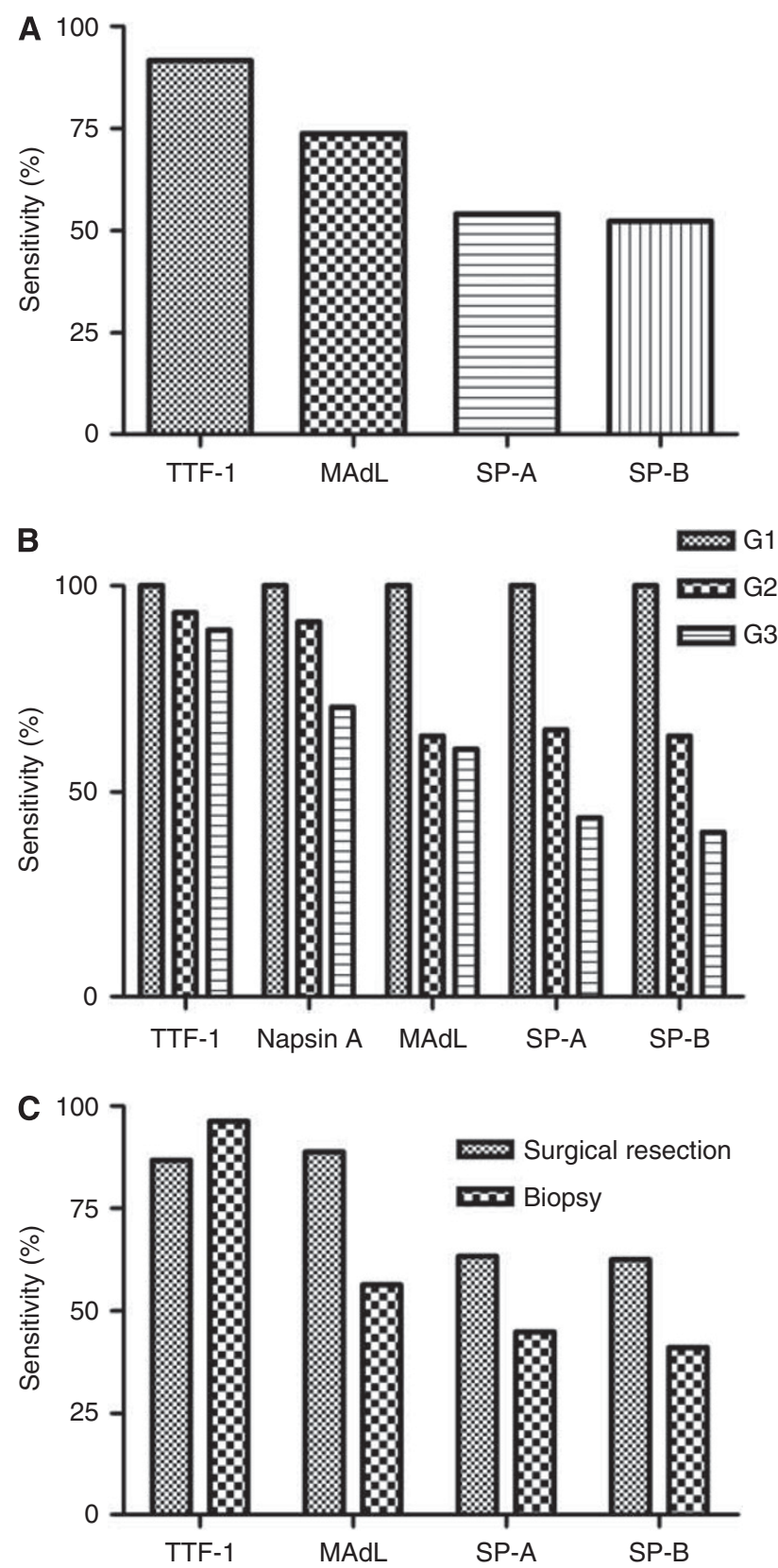

Figure 2 Bar plot depicting general sensitivity (A) of applied $\mathrm{HC}$ markers on 167 adenocarcinomas of the lung and sensitivity depending on grading (B) or specimen origin (C). Thyroid transcription factor-I was expressed in 154 out of 167 (92.2\%) cases of adenocarcinomas and MAdL in 124 out of 167 (74.2) cases. The surfactant proteins SP-A and SP-B were found to be expressed in 92 (55\%) and 88 (52.6\%) of 167 samples, respectively.

hypothesised that most adenocarcinomas probably arise from bronchoalveolar stem cells, from which Clara cells or AECII derive (Kim et al, 2009), we immunised mice with a cytoplasmic fraction of AECII to generate a diagnostically relevant antibody to differentiate adenocarcinomas of the lung. One of the clones, designated MAdL, demonstrated a high specificity for pulmonary adenocarcinomas in HOPE-fixed tissues. Additionally, MAdL reacts with AECII and alveolar macrophages, whereas macrophages from other locations showed no reaction (Figure $1 \mathrm{E}$ and $\mathrm{F}$ ). This may suggest phagocytosis rather than synthesis of the MAdL antigen in macrophages. To expand the application spectrum to

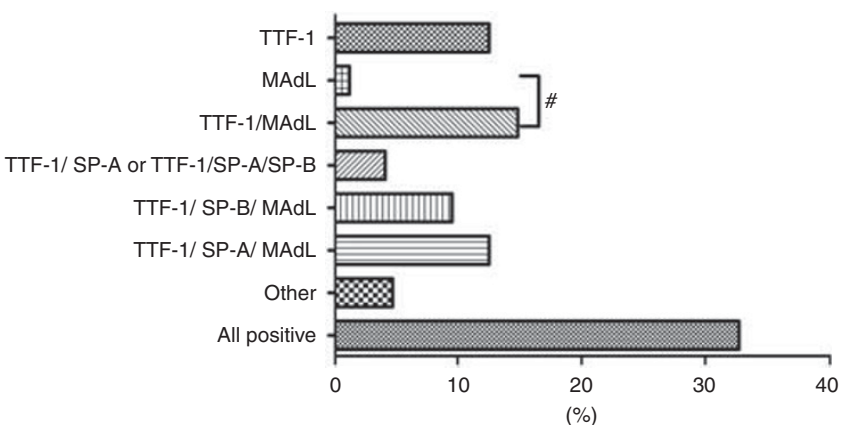

Figure 3 Observed expression patterns of applied IHC markers for 167 cases of adenocarcinomas of the lung. Within the observed patterns, $55(32.7 \%)$ cases were positive for all the markers. Thyroid transcription factor-I alone was observed in 21 cases (I2.5\%) and MAdL alone in 2 cases (I.1\%). Thyroid transcription factor-I and MAdL as the only expressed markers were observed in 25 cases (I4.9\%), whereas TTF-I/ MAdL/SP-A or TTF-I/MAdL/SP-B stated for 2 I (12.5\%) or 16 (9.5\%) cases, respectively. Expression of TTF-I and SP-A or TTF-I with both surfactant proteins counted for each seven (4.1\%) cases. Less frequent combinations of markers included TTF-I/SP-B, MAdL/SP-A, MAdL/SP-B, MAdL/SP-A/SP-B and SP-AVSP-B and were grouped as 'other' with $4.7 \%$. No expression of any marker was observed in six cases (3.5\%). The possible diagnostic benefit of MAdL is displayed with '\#' and accounts for 27 cases (16\%) within the investigated collective.

FFPE tissues, an extensive array of pretreatments was investigated for an optimal staining result. Here, we present a newly generated, applied and evaluated antibody for differentiation of adenocarcinomas from squamous cell carcinomas of the lung, in addition to the optimal application protocol.

\section{Diagnosis of lung cancer}

Lung cancer is the most common and deadliest cancer in the world. Among the 12.7 millions of cancer incidence worldwide in 2008 , lung cancer accounts for $13 \%$ or more than 1.4 million cases with fatal outcome (Jemal et al, 2011). Within the last decades, adenocarcinoma has become the most prevalent subtype of lung cancer (Boyle and Levin, 2009), which accounts for almost half of diagnosed cases (Curado et al, 2007). Over a long period, the simple discrimination between SCLC and NSCLCs used to be sufficient regarding therapeutic intervention. As new treatments such as growth factor receptor mutation analyses offer targeted therapies, the precise differentiation of NSCLC has to keep up with these developments (Ramalingam et al, 2011). As diagnostics usually have to cope with scarce tumour material, which hardly allows satisfactory differentiation of tumour entities by morphology and heterogeneity of the material is well known, development and application of specific markers are crucial. The majority of metastases within the lung are adenocarcinomas (Dail and Hammar, 2008). Therefore, discrimination between primary lung adenocarcinoma and metastasis influences the subsequent therapies (Tanaka et al, 2008; Zheng and Fernando, 2010). Routine diagnostic procedures are based on morphology and immunohistochemical detection of specific antigens. Up to date, there is still little consensus about the applied antibodies or other standards. The antibody panel is highly heterogenous, and depending on the study it includes up to five different markers (Ring et al, 2009).

\section{MAdL delivers high sensitivity and specificity for adenocarcinomas of the lung}

Thyroid transcription factor-1 is commonly used as a basic marker for lung carcinomas, with a reported sensitivity range for lung adenocarcinomas between 75 and $80 \%$ (Lau et al, 2002; Jagirdar, 2008 ) and $92 \%$ according to our own study (see Table 3): However, 

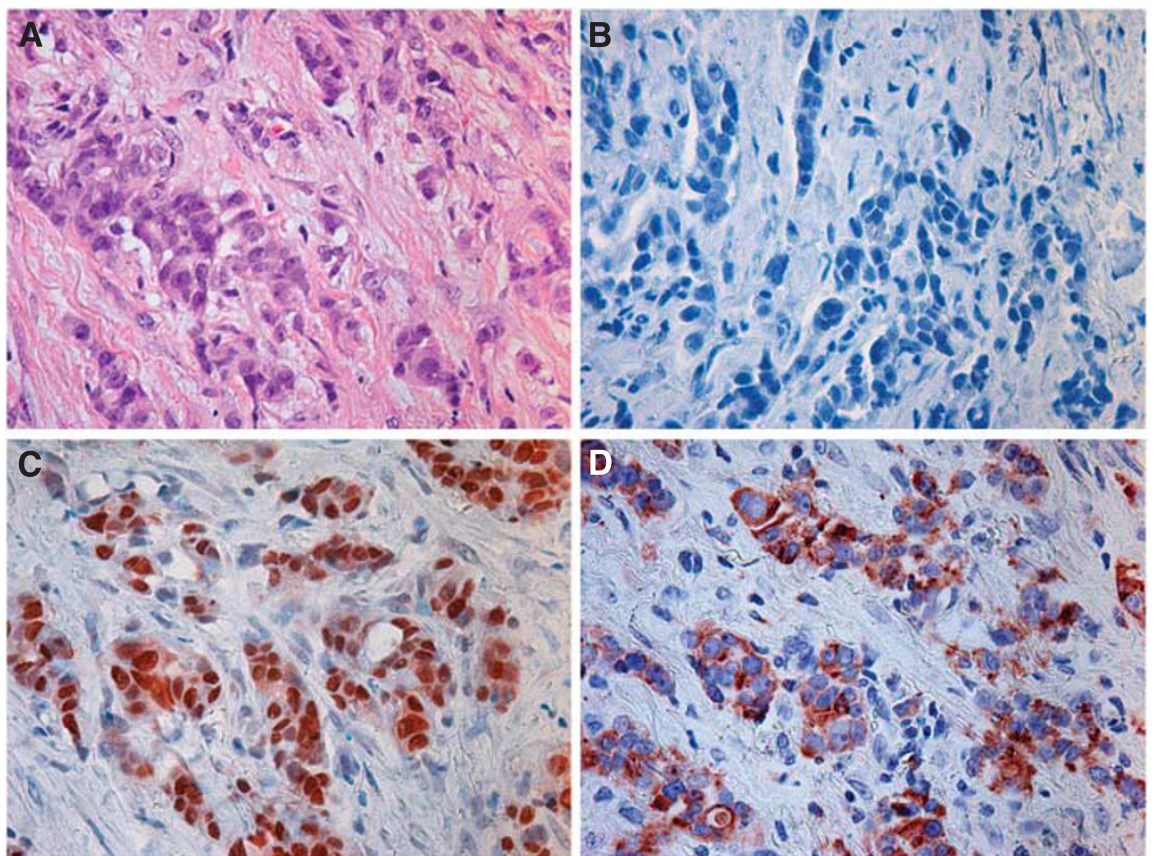

Figure 4 Photomicrograph of IHC on a case of pleura carcinosis from pulmonary adenocarcinoma origin. Hematoxylin-eosin-stained overview (A). No expression of either SP-A or SP-B was observed (data only shown for SP-A; B). Targeting TTF-I resulted in strong nuclear (C) or cytoplasmic staining for MAdL (D). All images were at $\times 400$ magnification.
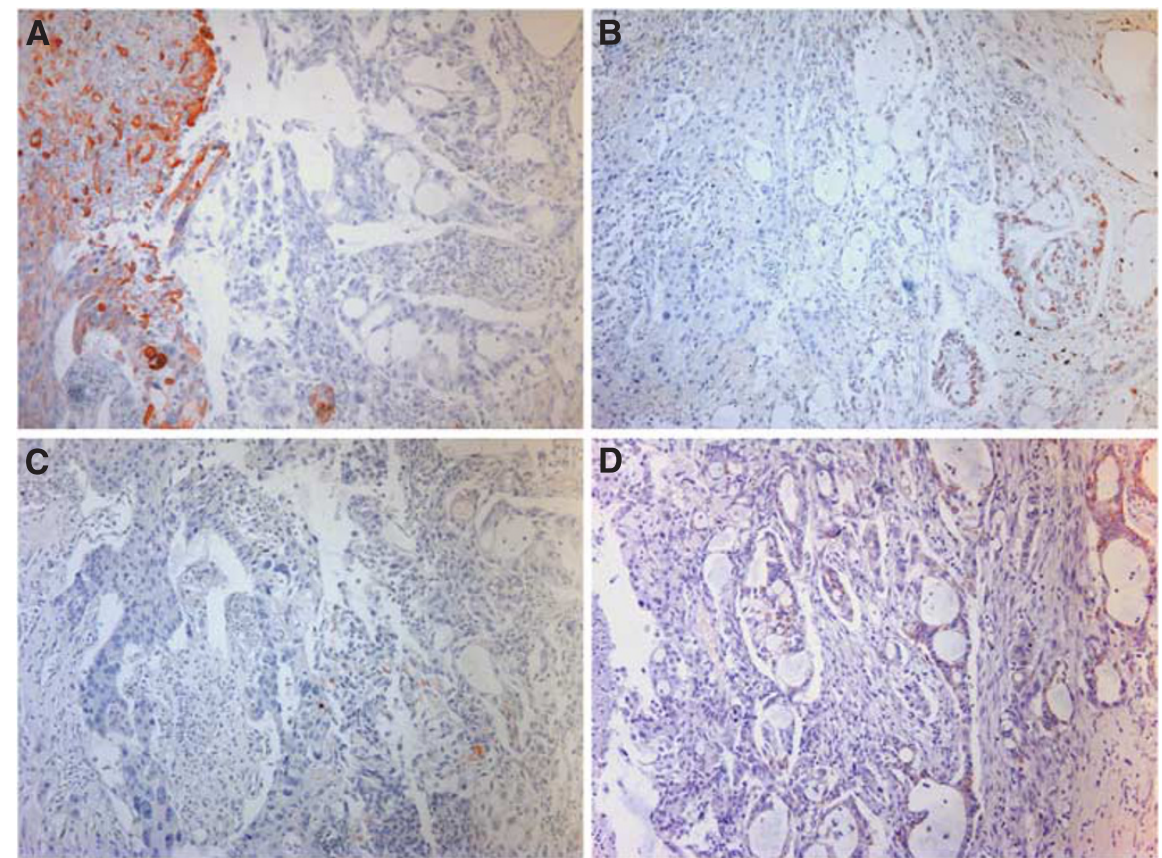

Figure 5 Photomicrograph of $\mathrm{IHC}$ on a case of adenosquamous carcinoma of the lung. Squamous-differentiated tumour component revealed a strong CK5/6 positivity $(\mathbf{A})$. Adenoid component of the tumour shows a distinct nuclear signal for TTF-I (B) and a patchy staining for SP-B (C). Cytoplasmic signals for MAdL could be observed, in contrast to TTF-I, in the majority of glands (D).

TTF-1 can also be found in other lung tumour entities such as SCLC, large-cell neuroendocrine carcinomas and carcinoids (Folpe et al, 1999). Additionally, TTF-1 is reported to be expressed inversely in relation to tumour differentiation (Lau et al, 2002; Jagirdar, 2008; Yang and Nonaka, 2010). Regarding the reactivity with other (Klingen et al, 2010) and lung malignancies, TTF-1 is not sufficient as a stand-alone marker for diagnosis of primary lung adenocarcinomas. In addition, SP-B and SP-A are usually applied to further discriminate between squamous cell carcinomas and adenocarcinomas. For SP-A, the sensitivity ranges between 45 and $64 \%$, and its expression declines notably with loss of differentiation (Yang and Nonaka, 2010). As the highly specific SP-A clone PE-10 (Dempo et al, 1987; Sugiyama et al, 1992; Goldmann et al, 2009) is no more commercially available and the 
follow-up clone displays cross-reactivity with intestinal epithelia and carcinomas (authors own observations), the specificity for pulmonary adenocarcinomas is not warranted. Therefore, for means of differentiation, SP-B can be applied but with a lack of sensitivity (52.6\%, see Figure 2A). Applying MAdL as a second-line marker improves sensitivity to $74.2 \%$ in contrast to the commonly used surfactant proteins. Hence, we were able to show in an extensive study that MAdL is only expressed in alveolar macrophages, AECII and proximal tubules of the kidney in nonmalignant tissues. Emphasising on malignant tissues, MAdL can exclusively be found in adenocarcinomas, whereas adenoiddifferentiated extrapulmonary malignancies, which usually metastasise to the lung (Dail and Hammar, 2008), were not detected. Furthermore, only adenoid parts of adenosquamous carcinomas, as well as one case of chromophile renal cell carcinoma, displayed positivity for MAdL. This reactivity may come in line with the observed expression in its non-malignant tissue origin, the proximal renal tubules (Figure 1A). In contrast to TTF-1, no reactivity with non-adenous lung carcinomas, such as neuroendocrine carcinomas, large-cell neuroendocrine carcinomas, as well as small-cell bronchial carcinoma and carcinoids, was observed. This counts for a superior quality of MAdL as a second-line marker for subdifferentiation of lung cancer. Owing to the way of generating MAdL by immunisation of mice with preparations of fractions of primary human AECII, we do not yet know the target molecule of MAdL. The knowledge of this target molecule would allow insights into the biological relevance of MAdL expression in different tissues. Appropriate studies are currently underway to uncover this target molecule, which use techniques such as two-dimensional gel electrophoresis, immunoprecipitation techniques, accompanied by mass spectrometry and immunogold electron microscopy.

\section{Sensitivity of MAdL persists in biopsy material and during dedifferentiation}

Biopsy specimens, in general, inhabit only a small fraction of the whole tumour compared with surgical specimens. Therefore, the heterogeneity in expression of applied markers has a more severe effect on the sensitivity. In contrast to SP-A (44.9\%) and SP-B (41\%), MAdL retained a higher sensitivity (56.4\%) in biopsy material. Interestingly, MAdL (88.8\%) showed a comparable sensitivity to TTF-1 (86.7\%) in surgically resected specimens (Figure 2C). In addition to sensitivity in biopsy specimen, we further investigated the sensitivity of MAdL depending on tumour grading. In general, there is up to date no universal grading system for adenocarcinomas of the lung that is not disputed (Travis et al, 2011). However, it is widely accepted that loss of differentiation by increasing grading reflects likelihood of lymph node metastasis and reoccurrence after surgical intervention (Chung et al, 1982). Thyroid transcription factor-1 and napsin A both show an impressing sensitivity almost independent of grading, but with a noteworthy lack of specificity for adenocarcinomas of the lung. The surfactant proteins range lower in sensitivity and suffer, in addition, from a loss in G2 to G3 tumours. The MAdL as a marker with sensitivity in between napsin A and SP-A or SP-B will add a decent advantage based on its specificity and persistent expression in terms of grading stages or specimen origin.

\section{Diagnostic benefit of applying MAdL}

The currently arising targeted therapies comprising receptor tyrosine kinase inhibitors such as gefitinib or erlotinib offer a true benefit for the patients (Mok et al, 2009). With regard to the therapy decision, one has to bear in mind that this is not exclusively achieved by molecular-based analysis as for EGFR mutations (Rosell et al, 2009), but also deeply depends upon the previous diagnosis of NSCLC and subdifferentiation into adenocarcinomas. Without a concrete and specific diagnosis, the subsequent molecular-based analyses and therapies will be impaired. Here, MAdL as a new and specific marker for adenocarcinomas of the lung offers a diagnostic benefit of $16 \%$ if used as a second-line marker besides TTF- 1 . As $12.7 \times 10^{6}$ cases of cancer have been globally diagnosed in 2008 , with $13 \%\left(1.6 \times 10^{6}\right)$ of which are lung cancers (Jemal et al, 2011), with almost $50 \%$ of adenocarcinomas (Curado et al, 2007), a 16\% higher diagnosis because of MAdL would account for 132000 more cases each year worldwide. In addition to EGFR-targeting therapies, new molecular insights into lung cancer development currently have emerged. K-RAS mutations appear in $25 \%$ of adenocarcinomas and may be a promising target of new therapeutic strategies (Sunaga et al, 2011), as well as the recently described EML4 protein (Radtke et al, 2010) and its EML4-ALK oncoprotein counterpart (Gerber and Minna, 2010). This growing number of insights into molecular events during lung cancer development will doubtlessly lead to better therapy, but the diagnosis of certain NSCLC subtypes has to keep pace with these events. Therefore, we developed MAdL as a new second-line marker for adenocarcinomas of the lung that might improve the primary diagnoses on which targeted therapies depend.

\section{ACKNOWLEDGEMENTS}

We thank Thomas Scholzen (PhD) for his contributions to the initial antibody development, including immunisation and antibody screening. We also thank Tanja Zietz, Maria Lammers, Steffi Fox and Jasmin Tiebach for excellent technical assistance.

\section{REFERENCES}

Barlési F, Pinot D, Legoffic A, Doddoli C, Chetaille B, Torre JP, Astoul P (2005) Positive thyroid transcription factor 1 staining strongly correlates with survival of patients with adenocarcinoma of the lung. Br J Cancer 93(4): $450-452$

Boggaram V (2003) Regulation of lung surfactant protein gene expression. Front Biosci 8: d751-d764

Boyle P, Levin B (2009) World Cancer Report 2008. International Agency for Research on Cancer, World Health Organization. WHO Press: Geneva

Brasch F, Ochs M, Kahne T, Guttentag S, Schauer-Vukasinovic V, Derrick M, Johnen G, Kapp N, Muller KM, Richter J, Giller T, Hawgood S, Buhling F (2003) Involvement of napsin A in the C- and $\mathrm{N}$-terminal processing of surfactant protein $\mathrm{B}$ in type-II pneumocytes of the human lung. J Biol Chem 278: $49006-49014$

Chuman Y, Bergman A, Ueno T, Saito S, Sakaguchi K, Alaiya AA, Franzén B, Bergman T, Arnott D, Auer G, Appella E, Jörnvall H, Linder S (1999) Napsin A, a member of the aspartic protease family, is abundantly expressed in normal lung and kidney tissue and is expressed in lung adenocarcinomas. FEBS Lett 462: 129-134

Chung CK, Zaino R, Stryker JA, O’Neill Jr M, DeMuth Jr WE (1982) Carcinoma of the lung: evaluation of histological grade and factors influencing prognosis. Ann Thorac Surg 33(6): 599-604

Curado MP, Edwards B, Shin HR, Storm H, Ferlay J, Heanu M, Boyle P (2007) Cancer Incidence in Five Continents Vol. IX. IARC Scientific Publications: Lyon Dail DH, Hammar SP (2008) Metastases to and from the lung. In Pulmonary Pathology, Tomashefski Jr JF (ed.) 3rd edn, Vol. II, p 735. Springer-Verlag: New York

Dejmek A, Naucler P, Smedjeback A, Kato H, Maeda M, Yashima K, Maeda J, Hirano T (2007) Napsin A (TA02) is a useful alternative to thyroid transcription factor-1 (TTF-1) for the identification of pulmonary adenocarcinoma cells in pleural effusions. Diagn Cytopathol 35: 493-497

Dempo K, Satoh M, Tsuji S, Mori M, Kuroki Y, Akino T (1987) Immunohistochemical studies on the expression of pulmonary 
surfactant apoproteins in human lung carcinomas using monoclonal antibodies. Pathol Res Pract 182: 669-675

Esteban E, Casillas M, Cassinello A (2009) Pemetrexed in first-line treatment of non-small cell lung cancer. Cancer Treat Rev 35(4): 364-373

Folpe AL, Gown AM, Lamps LW, Garcia R, Dail DH, Zarbo RJ, Schmidt RA (1999) Thyroid transcription factor-1: immunohistochemical evaluation in pulmonary neuroendocrine tumors. Mod Pathol 12(1): 5-8

Gerber DE, Minna JD (2010) ALK inhibition for non-small cell lung cancer: from discovery to therapy in record time. Cancer Cell 18(6): $548-451$

Goldmann T, Drömann D, Marzouki M, Schimmel U, Debel K, Branscheid D, Zeiser T, Rupp J, Gerdes J, Zabel P, Vollmer E (2005) Tissue microarrays from HOPE-fixed specimens allow for enhanced high throughput molecular analyses in paraffin-embedded material. Pathol Res Pract 201: 599-602

Goldmann T, Kähler D, Schultz H, Abdullah M, Lang DS, Stellmacher F, Vollmer E (2009) On the significance of surfactant protein-A within the human lungs. Diagn Pathol 12; 4: 8

Goldmann T, Vollmer E, Gerdes J (2003) What's cooking? Detection of important biomarkers in HOPE-fixed paraffin embedded tissues eliminates the need for antigen retrieval. Am J Pathol 163: 2638-2640

Hirano T, Gong Y, Yoshida K, Kato Y, Yashima K, Maeda M, Nakagawa A, Fujioka K, Ohira T, Ikeda N, Ebihara Y, Auer G, Kato H (2003) Usefulness of TA02 (napsin A) to distinguish primary lung adenocarcinoma from metastatic lung adenocarcinoma. Lung Cancer 41: 155-162

Jagirdar J (2008) Application of immunohistochemistry to the diagnosis of primary and metastatic carcinoma to the lung. Arch Pathol Lab Med 132: $384-396$

Jemal A, Bray F, Center MM, Ferlay J, Ward E, Forman D (2011) Global cancer statistics. CA Cancer J Clin 61(2): 69-90

Kargi A, Gurel D, Tuna B (2007) The diagnostic value of TTF-1, CK 5/6, and p63 immunostaining in classification of lung carcinomas. Appl Immunohistochem Mol Morphol 15: 415-420

Kaufmann O, Georgi T, Dietel M (1997) Utility of 123C3 monoclonal antibody against CD56 (NCAM) for the diagnosis of small cell carcinomas on paraffin sections. Hum Pathol 28(12): 1373-1378

Kim HS, Park K, Jun HJ, Yi SY, Lee J, Ahn JS, Park YH, Kim S, Lee S, Ahn MJ (2009) Comparison of survival in advanced non-small cell lung cancer Patients in the pre- and post-gefitinib eras. Oncology 76: 239-246

Köhler G, Milstein C (1975) Continuous cultures of fused cells secreting antibody of predefined specificity. Nature 256(5517): 495-497

Klingen TA, Chen Y, Gundersen MD, Aas H, Westre B, Sauer T (2010) Thyroid transcription factor-1 positive primary breast cancer: a case report with review of the literature. Diagn Pathol 17; 5: 37

Lau S, Luthringer D, Eisen R (2002) Thyroid transcription factor-1: a review. Appl Immunohistochem Mol Morphol 10: 97-102

Lee HY, Ahn MJ, Park YH, Ahn JS, Kim BS, Kim HK, Kim HT, Ryoo HM, Bae SH, Lee SS, Choi K, Hong DS, Lee KH, Kwon JH, Choi IS, Kim BS, Lee NS, Gong SJ, Park K (2009) Adenocarcinoma has an excellent outcome with pemetrexed treatment in Korean patients: a prospective, multicenter trial. Lung Cancer 66(3): 338-343

Mizutani Y, Nakajima T, Morinaga S, Gotoh M, Shimosato Y, Akino T, Suzuki A (1988) Immunohistochemical localization of pulmonary surfactant apoproteins in various lung tumours. Special reference to nonmucus producing lung adenocarcinomas. Cancer 61: 532-537

Mok TS, Wu YL, Thongprasert S, Yang CH, Chu DT, Saijo N, Sunpaweravong P, Han B, Margono B, Ichinose Y, Nishiwaki Y, Ohe Y, Yang JJ, Chewaskulyong B, Jiang H, Duffield EL, Watkins CL, Armour AA, Fukuoka M (2009) Gefitinib or carboplatin-paclitaxel in pulmonary adenocarcinoma. $N$ Engl J Med 361(10): 947-957

Pechkovsky DV, Goldmann T, Ludwig C, Prasse A, Vollmer E, MullerQuernheim J, Zissel G (2005) CCR2 and CXCR3 agonistic chemokines are differently expressed and regulated in human alveolar epithelial cells type II. Respir Res 6: 75

Pechkovsky DV, Goldmann T, Vollmer E, Muller-Quernheim J, Zissel G (2006) Interleukin-18 expression by alveolar epithelial cells type II in tuberculosis and sarcoidosis. FEMS Immunol Med Microbiol 46(1): 30-38
Pignal F, Maurice M, Feldmann G (1982) Immunoperoxidase localization of albumin and fibrinogen in rat liver fixed by perfusion or immersion: effect of saponin on the intracellular penetration of labeled antibodies. J Histochem Cytochem 10: 1004-1014

Radtke J, Rezaie SG, Kugler Ch, Zabel P, Schultz H, Vollmer E, Goldmann T, Lang DS (2010) Expression analysis of EML4 in normal lung tissue and non-small cell lung cancer (NSCLC) in the absence and presence of chemotherapeutics. Rom J Morphol Embryol 51(4): 647-653

Ramalingam SS, Owonikoko TK, Khuri FR (2011) Lung cancer: New biological insights and recent therapeutic advances. CA Cancer J Clin 61(2): 91-112

Ring BZ, Seitz RS, Beck RA, Shasteen WJ, Soltermann A, Arbogast S, Robert F, Schreeder MT, Ross DT (2009) A novel five-antibody immunohistochemical test for subclassification of lung carcinoma. Mod Pathol 22(8): $1032-1043$

Rosell R, Moran T, Queralt C, Porta R, Cardenal F, Camps C, Majem M, Lopez-Vivanco G, Isla D, Provencio M, Insa A, Massuti B, GonzalezLarriba JL, Paz-Ares L, Bover I, Garcia-Campelo R, Moreno MA, Catot S, Rolfo C, Reguart N, Palmero R, Sánchez JM, Bastus R, Mayo C, BertranAlamillo J, Molina MA, Sanchez JJ, Taron M (2009) Screening for epidermal growth factor receptor mutations in lung cancer. $N$ Engl J Med. 361(10): 958-967

Schellens JH, Vincent A, van Zandwijk N, Groen HJ (2009) Randomized phase ii and pharmacogenetic study of pemetrexed compared with pemetrexed plus carboplatin in pretreated patients with advanced nonsmall-cell lung cancer. J Clin Oncol 27(12): 2038-2045

Smit EF, Burgers SA, Biesma B, Smit HJ, Eppinga P, Dingemans AM, Joerger M, Srinivasan M, Sedmak D, Jewell S (2001) Effect of fixatives and tissue processing on the content and integrity of nucleic acids. Am J Pathol 161: $1961-1971$

Srinivasan M, Sedmak D, Jewell S (2002) Effect of fixatives and tissue processing on the content and integrity of nucleic acids. Am J Pathol 161(6): $1961-1971$

Sugiyama K, Kawai T, Nakanishi K, Suzuki M (1992) Histochemical reactivities of lectins and surfactant apoprotein in pulmonary adenocarcinomas and their metastases. Mod. Pathol 5: 273-276

Sunaga N, Shames DS, Girard L, Peyton M, Larsen JE, Imai H, Soh J, Sato M, Yanagitani N, Kaira K, Xie Y, Gazdar AF, Mori M, Minna JD (2011) Knockdown of oncogenic KRAS in non-small cell lung cancers suppresses tumor growth and sensitizes tumor cells to targeted therapy. Mol Cancer Ther 10(2): 336-346

Tanaka Y, Maniwa Y, Nishio W, Yoshimura M, Okita Y (2008) The optimal timing to resect pulmonary metastasis. Eur J Cardiothorac Surg 33(6): $1135-1138$

Travis W (2002) Pathology of lung cancer. Clin Chest Med 23: 65-81

Travis WD, Brambilla E, Noguchi M, Nicholson AG, Geisinger KR, Yatabe Y, Beer DG, Powell CA, Riely GJ, Van Schil PE, Garg K, Austin JH, Asamura H, Rusch VW, Hirsch FR, Scagliotti G, Mitsudomi T, Huber RM, Ishikawa Y, Jett J, Sanchez-Cespedes M, Sculier JP, Takahashi T, Tsuboi M, Vansteenkiste J, Wistuba I, Yang PC, Aberle D, Brambilla C, Flieder D, Franklin W, Gazdar A, Gould M, Hasleton P, Henderson D, Johnson B, Johnson D, Kerr K, Kuriyama K, Lee JS, Miller VA, Petersen I, Roggli V, Rosell R, Saijo N, Thunnissen E, Tsao M, Yankelewitz D (2011) International association for the study of lung cancer/American thoracic society/European respiratory society international multidisciplinary classification of lung adenocarcinoma. J Thorac Oncol 6(2): 244-285

Van Lerberghe W, Evans T, Rasanathan K, Mechbal A (2008) The World Health Report 2008: Primary Health Care Now More Than Ever. World Health Organization: Geneva, p 8

Yang M, Nonaka D (2010) A study of immunohistochemical differential expression in pulmonary and mammary carcinomas. Mod Pathol 23: 654-661

Zheng Y, Fernando HC (2010) Surgical and nonresectional therapies for pulmonary metastasis. Surg Clin North Am 90(5): 1041 - 1051

Zissel G, Ernst M, Rabe K, Papadopoulos T, Magnussen H, Schlaak M, Müller-Quernheim J (2000) Human alveolar epithelial cells type II are capable of regulating T-cell activity. J Investig Med 48: 66-75

This work is published under the standard license to publish agreement. After 12 months the work will become freely available and the license terms will switch to a Creative Commons Attribution-NonCommercial-Share Alike 3.0 Unported License. 